\title{
Igneous stratigraphy and internal structure of the Little Minch Sill Complex, Trotternish Peninsula, northern Skye, Scotland
}

\author{
SALLY A. GIBSON* \& ADRIAN P. JONES $\dagger$
}

School of Geological Sciences, Kingston Polytechnic, Kingston upon Thames, KT1 2EE, U.K.

(Received 1 May 1990; accepted 20 September 1990)

\begin{abstract}
Detailed sampling of the Little Minch Sill Complex reveals that it is composed of both single and multiple sills. These are formed of three main, genetically related units: picrite, picrodolerite and crinanite, which are the result of differentiation of an alkali-olivine basalt magma (approximately $10 \% \mathrm{MgO}$ ) in an upper-crustal magma chamber. Variations in igneous stratigraphy and the presence of internal chills in the Trotternish sills suggest that they were emplaced by multiple intrusion and subsequently differentiated in situ. Changes in petrography adjacent to pegmatite veins and textures within picrite units indicate compaction and filter-pressing were important processes after emplacement. Rhythmic layering ( $1 \mathrm{~cm}$ to $1 \mathrm{~m}$ thick) is conspicuous in the sills near contacts but does not involve cryptic mineral variation. Such modal layering may be more common than realised in relatively small-scale intrusions and may be modelled in terms of in situ differentiation under conditions of significant undercooling in a changing thermal gradient at the synthetic forsterite-diopside-anorthite eutectic.
\end{abstract}

\section{Introduction}

A large Tertiary sill complex, the Little Minch Sill Complex (LMSC; Gibb \& Gibson 1989), outcrops on the Trotternish Peninsula of northern Skye and adjacent islands, which include the Shiant Isles and Raasay (Fig. 1). The LMSC covers a large area $\left(4000 \mathrm{~km}^{2}\right)$ and represents a considerable volume of magma. Most of the published work on the LMSC relates to the classic sills on the Shiant Isles (Walker, 1930; Drever \& Johnston, 1957, 1965; Gibb, 1973; Gibb \& Henderson, 1984, 1989). The sills on the Trotternish Peninsula have formed the basis of relatively few publications (Walker, 1931, 1932; Anderson \& Dunham, 1966; T. Simkin, unpub. Ph.D. thesis, Univ. Princeton, 1965; Simkin, 1967) considering their excellent lateral exposure and relatively unaltered nature. This study is primarily concerned with the field relations and petrography of the Trotternish sills, and the geochemistry and petrogenesis of the LMSC are discussed elsewhere (S. A. Gibson, unpub. Ph.D. thesis, Kingston Polytechnic, 1988; Gibson, 1990).

\section{Geological setting}

The most extensive and laterally persistent outcrops of the LMSC occur on the Trotternish Peninsula where the thickness of individual sills varies from

* Present address: Department of Geological Sciences, University of Durham, South Road, Durham DHI $3 \mathrm{LE}$, England.

$\dagger$ Present address; Department of Geological Sciences, University College London, Gower Street, London WClE 6BT, England. approximately $10 \mathrm{~m}$ to $130 \mathrm{~m}$. The LMSC post-dates the overlying Tertiary Skye lavas but is intruded by Tertiary late-stage basic dykes. The sills dip gently westward and transgress upwards through Jurassic sediments in a northerly direction. Lower contacts of the sills with Jurassic sediments are exposed at several localities, e.g. Meall Tuath and Rigg (localities 8 and 18, Fig. 2), but upper contacts are rare. It is unlikely that the whole thickness of the LMSC is completely exposed on the Trotternish Peninsula.

\section{Igneous stratigraphy}

Detailed field mapping and petrographic evidence suggest that the sills exposed on the Trotternish Peninsula (Fig. 2) are composed of either a single lithology, such as those at Osmigarry, Heribusta and Bornaskitaig (localities 6, 5,4), or multiple lithologies, such as those at Meall Tuath and Tottrome (localities $8,19)$. Three main lithologies are recognizable in the Trotternish sills: picrite, picrodolerite and crinanite (the definitions of Gibb \& Henderson [appendix, 1984] that incorporate the traditional names for the Shiant Isles material are used in this study). The multiple sills are generally formed of a lower picrite unit overlain by a crinanite and/or picrodolerite unit. In general the picrite maintains a regular thickness (approximately $50 \mathrm{~m}$ ) across the Trotternish Peninsula. This is greater than the thickness of picrite in the main Shiant Isles sill $(30 \mathrm{~m}$; Gibb \& Henderson, 1984). At Osmigarry a lower picrite sill, which also outcrops at Bornaskitaig, is separated from an upper crinanite/picrodolerite (which also outcrops at Heri- 


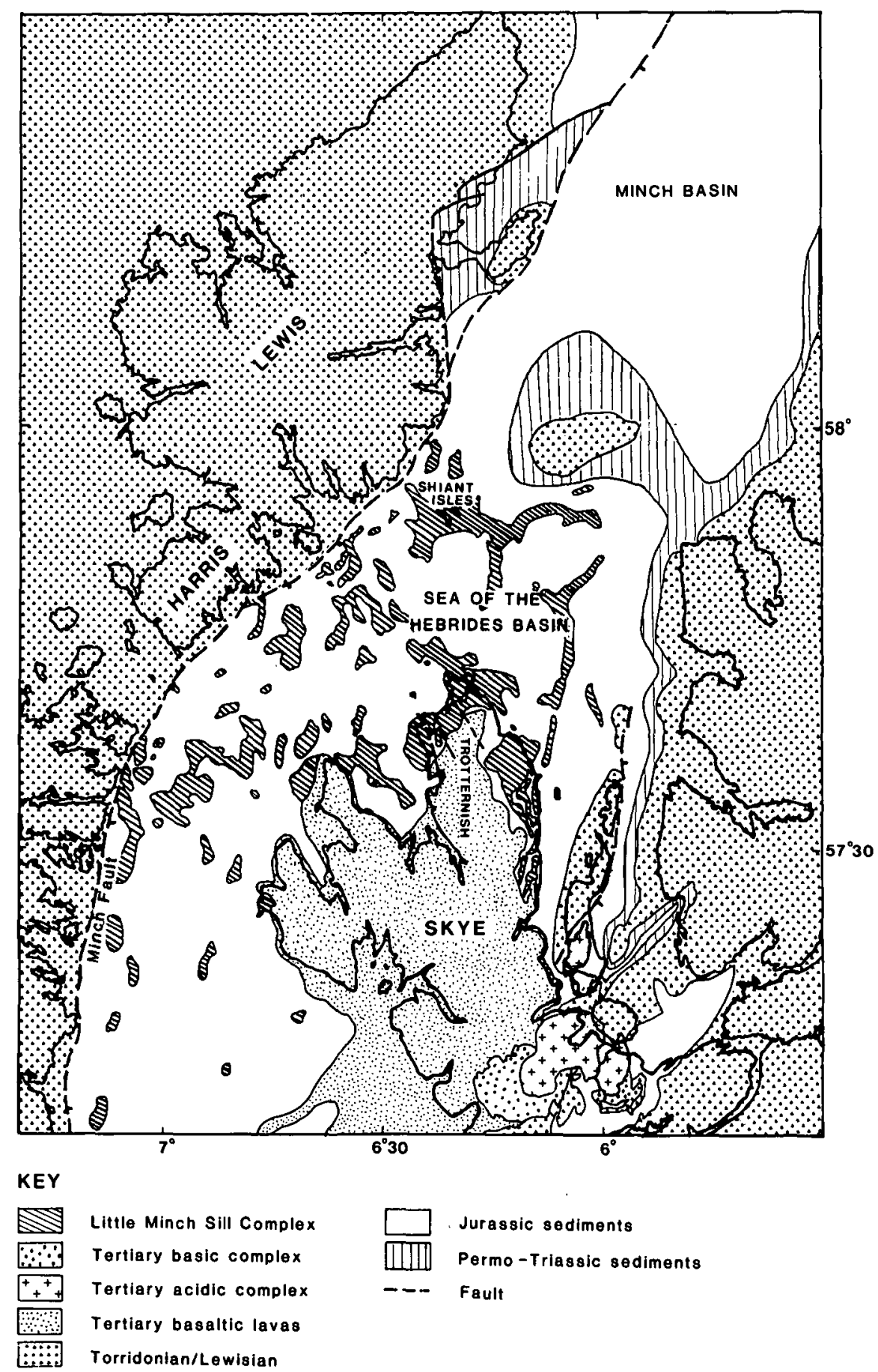

Figure 1. Outcrop of the Little Minch Sill Complex (after Chesher, Smythe \& Bishop, 1983).

busta) by $7 \mathrm{~m}$ of sediment (Fig. 3). At Creagan Iar, $2 \mathrm{~km}$ north of Osmigarry, the picrite and crinanite/ picrodolerite sills converge and the intervening sediments are absent. This picrite/picrodolerite contact is laterally extensive across the Trotternish Peninsula and can be traced north to Meall Tuath, east to Flodigarry and possibly southeast to Tottrome (Fig. 2). No evidence of chilling is present at this contact which resembles the picrite/picrodolerite 'discontinuity' in the main Shiant Isles sill (Drever, 1953; Gibb \& Henderson, 1989).

The picrite sill which outcrops at Rigg may be an offshoot of the sill at Tottrome. The crinanite sill which outcrops at Holm (NG $519514 ; 25 \mathrm{~m}$ thick) and Leac Tressirnish $(10 \mathrm{~m})$ decreases in thickness northwards and forms the upper unit $(5 \mathrm{~m})$ of the multiple sill at Tottrome (Fig. 2). The relationship of the crinanite sills, which outcrop along the east coast between Culnaknock and Staffin, and the rest of the complex is unclear. They lie on the upthrown side of a NW-SE fault, which separates them from sills at Dun Raisburgh and Dun Connavern, and are at a relatively low level in the stratigraphy of the LMSC. A crinanite sill ( $>20 \mathrm{~m}$ thick) is exposed beneath the main multiple sill at Meall Tuath and may be related to these crinanite sills and also the lower crinanite sill 


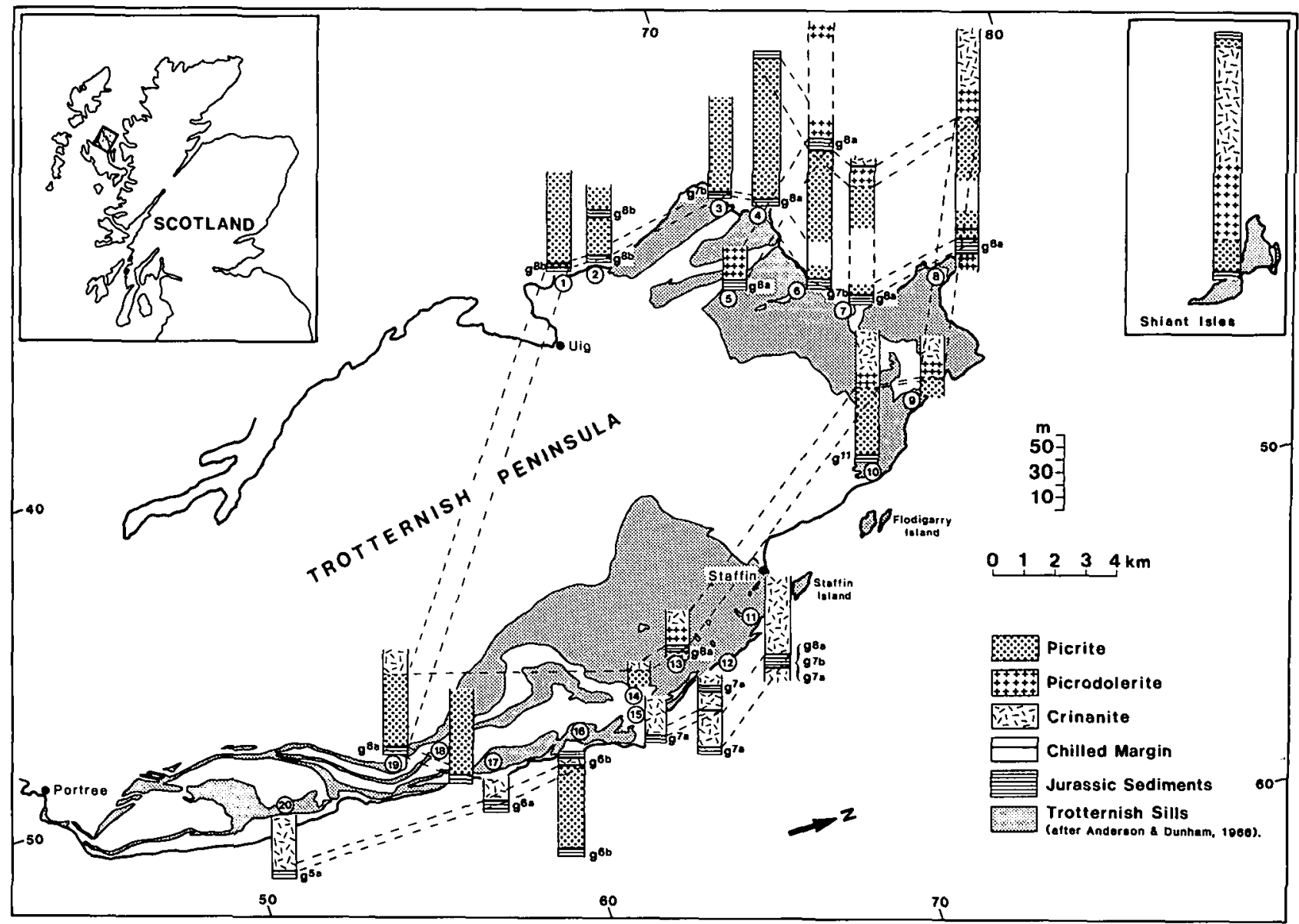

Figure 2. Variations in igneous stratigraphy of the Trotternish sills. Outcrop of the sills on the Trotternish Peninsula is from Anderson \& Dunham (1966). The stratigraphy of the Shiant Isles (Gibb \& Henderson, 1984) is shown for comparison. Sample localities are as follows: (1) Skudiburgh; (2) Kilbride Point; (3) Sgeir Lang; (4) Bornaskitaig; (5) Heribusta; (6) Osmigarry; (7) Creagan Iar; (8) Meall Tuath; (9) Balmaquien; (10) Flodigarry; (11) Staffin; (12) Loch Mealt; (13) Dun Raisburgh; (14) Culnaknock; (15) Dunn Connavern; (16) Invertote; (17) Leac Tressirnish; (18) Rigg; (19) Tottrome; (20) Bearreraig.

s

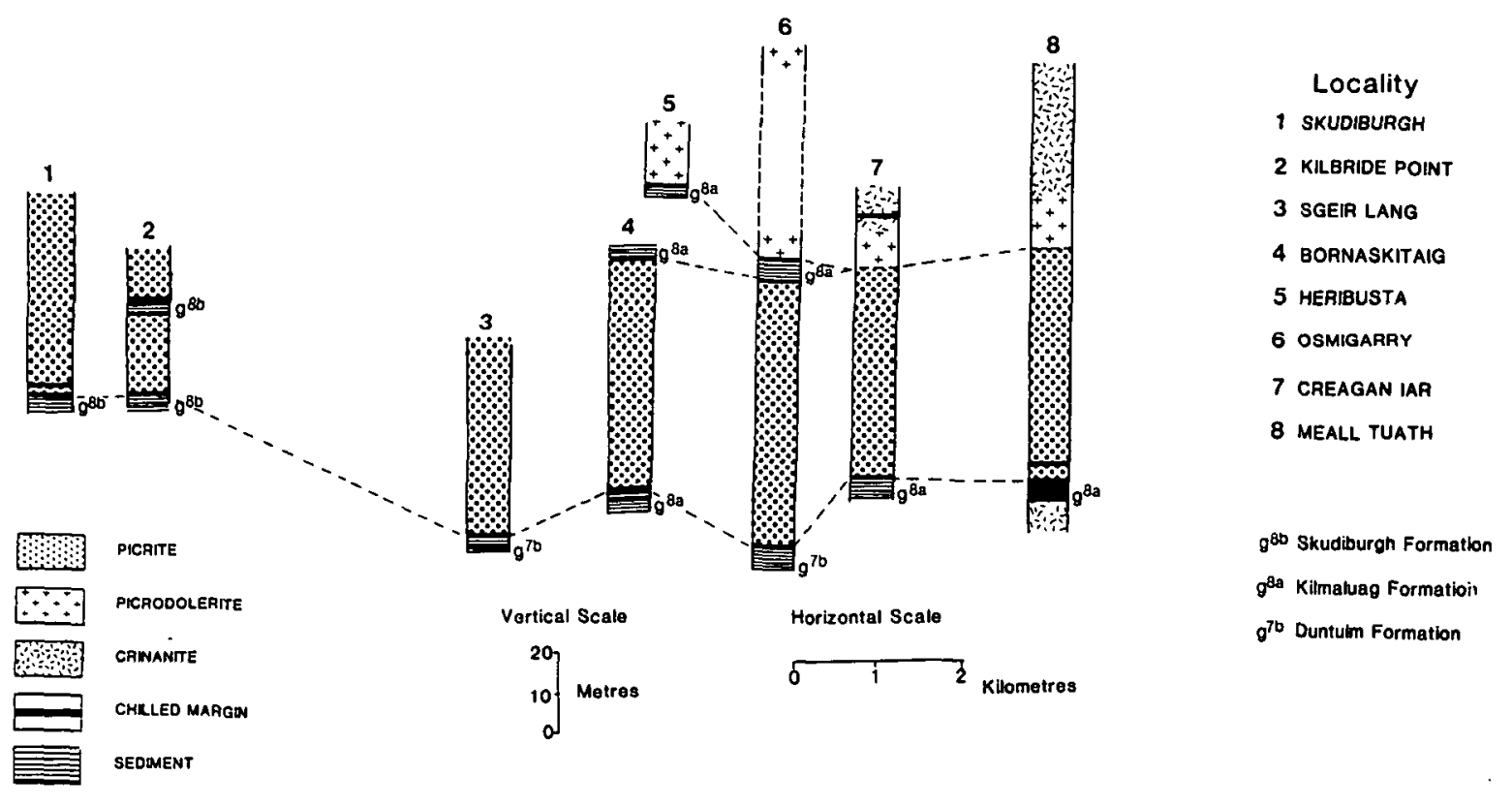

Figure 3. Transgressive relationships and variations in igneous stratigraphy of the sill in northwest Trotternish. 
on Garbh Eilean, Shiant Isles (Gibb \& Henderson, 1984).

\section{Internal structure}

\section{4.a. Internal contacts}

Well documented internal discontinuities are present in the main Shiant Isles sill at the picrite/picrodolerite junction (Drever, 1953; Gibb, 1973; Gibb \& Henderson, 1984, 1989) and at the crinanite/picrite junction (Gibb \& Henderson, 1984, 1989). An upper picrite unit has not been observed in any of the sills exposed on the Trotternish Peninsula but abrupt petrographic and geochemical changes occur at the picrite/picrodolerite junction (sections $5 \& 7$ ). Internal chills are present within the Trotternish sills at several localities. Such chills are highly significant in modelling the emplacement of the LMSC and have not been recorded previously in this area. At Skudiburgh and Meall Tuath internal chills occur within $5 \mathrm{~m}$ of the lower contact of the picrite sill with sediments. At both localities the upper picrite unit appears to be chilled against the lower one. At Creagan Iar an internal chill is present near the top of the sill. The upper crinanite unit ( $>5 \mathrm{~m}$ thick) is chilled against the lower crinanite/picrodolerite unit $(12 \mathrm{~m})$. An internal chill is also present within a few metres of the crinanite sill/sediment contact on Staffin Island [NG $490690]$. The upper unit appears to be chilled against the lower unit. In a recently exposed quarry section at Invertote (Fig. 4) a crinanite unit $(5 \mathrm{~m})$ is clearly chilled against a lower picrite unit $(42 \mathrm{~m})$. Further internal contacts are visible in the cliff at Kilt Rock [NG 509 655]. At Kilbride Point a lower picrite unit $(20 \mathrm{~m})$ is separated from an upper picrite unit (>15 $\mathrm{m}$ ) by $3 \mathrm{~m}$ of baked mudstone (Skudiburgh Formation). Both units are chilled against the sediment, which may be a sediment raft incorporated into the centre of the picrite sill or, more likely, a wedge of sediment which separates two sills.

\section{4.b. Layering}

The occurrence of rhythmic layering in the LMSC has been implied by Bell \& Harris (1986) and Brown (1969), and recorded in the syenites of Eilean Mhuire, Shiant Isles (Drever \& Johnston, 1957). Such layering is rarely described in relatively small-scale intrusions (e.g. Dunham, 1965) but is present at several localities in the LMSC. It usually occurs adjacent to sill contacts and is most noticeable on weathered surfaces. The layering is typically developed on a centimetre scale within a metre of the contact but is sometimes more extensive. Good examples occur in the cliffs beneath Duntulm Castle [NG 409 744], at Rubha nam Brathairean [NG 527 628], Flodigarry, Leac Tressirnish, Meall Tuath (Fig. 2), the Ascrib Islands [NG 304 632] and Flodigarry Island [NG 483 716], where layering has developed on a $1 \mathrm{~m}$ scale up to $40 \mathrm{~m}$ away from the lower contact between the sill and sediment (Fig. 5). At localities where sills make major transgressions, such as at Duntulm [NG 410 730], large rafts (up to $10 \mathrm{~m}$ ) of Jurassic sediment have been incorporated into the sills and layering has developed parallel to the surfaces of these rafts. Here, layer thickness increases but layer characteristics become less pronounced away from the contact. In general each layer has a mafic base which gradationally becomes more felsic and resistant to weathering upwards. The junctions between layers are abrupt. In thin section the layering at Rubha nam Brathairean is well defined by the variation in modal proportions of olivine, clinopyroxene and plagioclase (Fig. 6). No marked variation in mineral chemistry (cryptic layering) has been detected. The mafic bases are olivinerich $(14 \%)$ with large (up to $6 \mathrm{~mm}$ ), ophitic, zoned clinopyroxene $(29 \%)$ which enclose laths $(<2.5 \mathrm{~mm})$ of plagioclase feldspar $(51 \%)$. Titaniferous magnetite occurs interstitially, sometimes partially enclosing plagioclase, and forms approximately $6 \%$ of the less resistant layers. With increasing height above the mafic base, there is a corresponding increase in plagioclase $(59 \%)$ and a decrease in olivine $(7 \%)$ and clinopyroxene $(22 \%)$. The increase in clinopyroxene is accompanied by a change in habit, from large ophitic plates to small granules $(<2 \mathrm{~mm})$. Once more, the top of some layers is marked by a distinctive finegrained feldspathic horizon. The isolation of individual large laths of plagioclase by poikilitic plates of clinopyroxene suggests in situ crystallization. The distance between the plagioclase and olivine crystals is too great for them to have been supported by grainto-grain contact. The absence of cross-cutting layers and the relatively small thickness of the sills also support an origin by in situ crystallization. In the Trotternish sills layering commonly occurs close to contacts with sediments. At the time of emplacement, large differences in temperature between the magma and Jurassic sediments would produce large thermal gradients and a large $\Delta T$ at the contacts, where a boundary layer may have formed within the magma. In the Trotternish sills this appears to have been on a centimetre scale and the changing thermal gradient was a significant factor in the formation of layering (S. A. Gibson, unpub. Ph.D. thesis, Kingston Polytechnic, 1988). In larger intrusions such as Rhum and Skaergaard, $\Delta T$ would be small (perhaps $<5^{\circ} \mathrm{C}$ ) and of only minor significance at the margins.

By analogy with phase relationships in experimental Fe-free basaltic systems, undercooling at the forsterite-diopside-anorthite eutectic may account for the alternating phase relationships (S. A. Gibson, unpub. Ph.D. thesis, Kingston Polytechnic, 1988). After crystallization of spinel, the liquid would be driven towards the forsterite-diopside-anorthite eutectic. If undercooling occurred at this point olivine, 

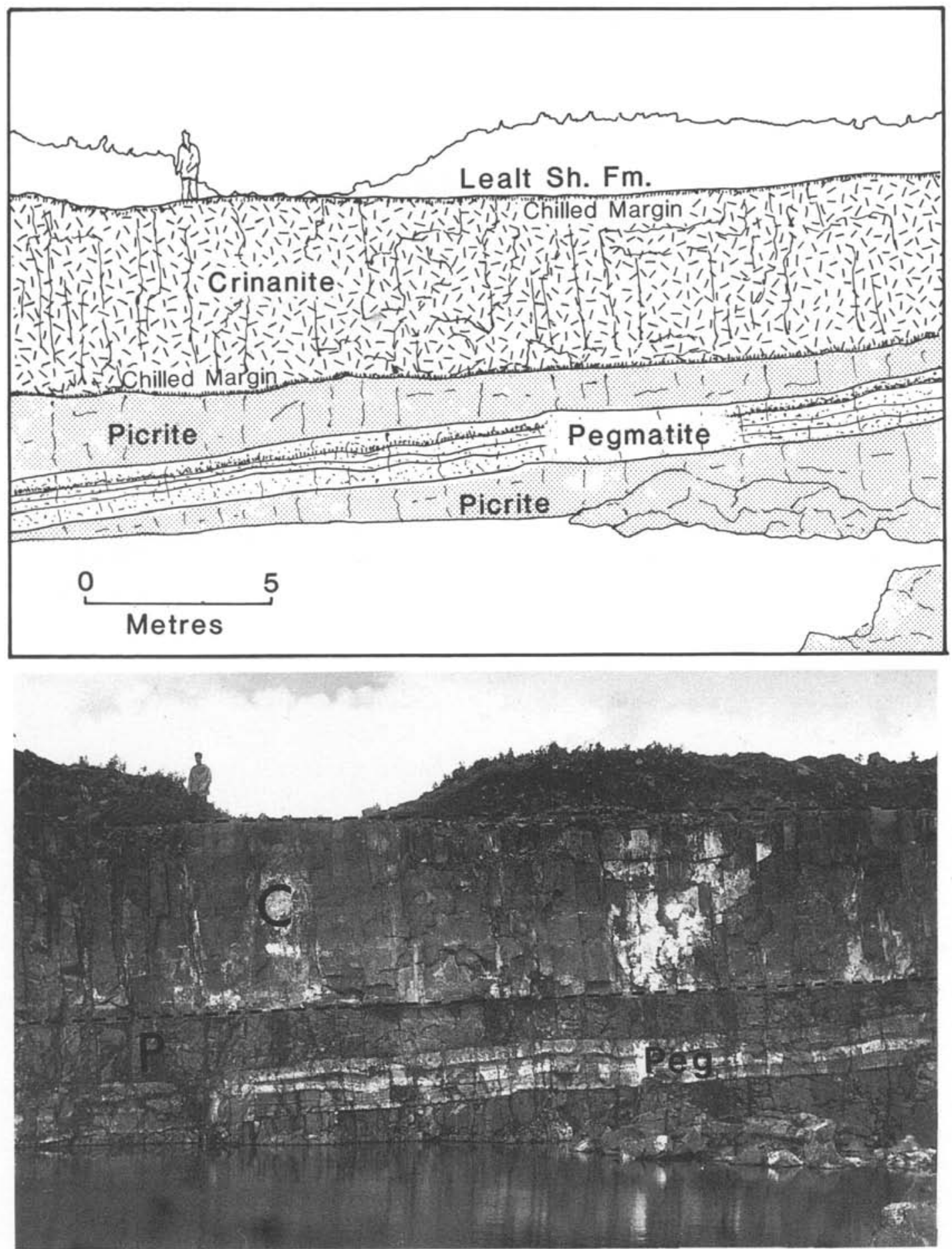

Figure 4. Quarry section at Invertote shows the contact between a lower picrite $(\mathrm{P})$ unit $(42 \mathrm{~m})$ and an upper crinanite $(\mathrm{C})$ unit $(5 \mathrm{~m})$. A pegmatite vein $(\mathrm{Peg})$ occurs near the top of the picrite unit.

being the easiest phase to nucleate, would crystallize and be accompanied by clinopyroxene. Clinopyroxene would have a relatively high growth/nucleation ratio and would become ophitic towards plagioclase. Olivine crystallization would drive the liquid towards the diopside-anorthite cotectic. At relatively small degrees of undercooling, clinopyroxene would have a high nucleation rate and form granular crystals (Carmichael, Turner \& Verhoogen, 1974). As clinopyroxene crystallized the liquid would become enriched with respect to plagioclase and would produce the feldspathic unit which is sometimes present at the top of layers. The relative rates of nucleation and growth appear to have been more important than the sequence of phases at the liquidus in the formation of layering at the margins of the Trotternish sills.

\section{Petrography}

Petrugraphic variations in the LMSC relate primarily to modal differences in olivine, clinopyroxene and plagioclase. The main lithologies picrite, picrodolerite 


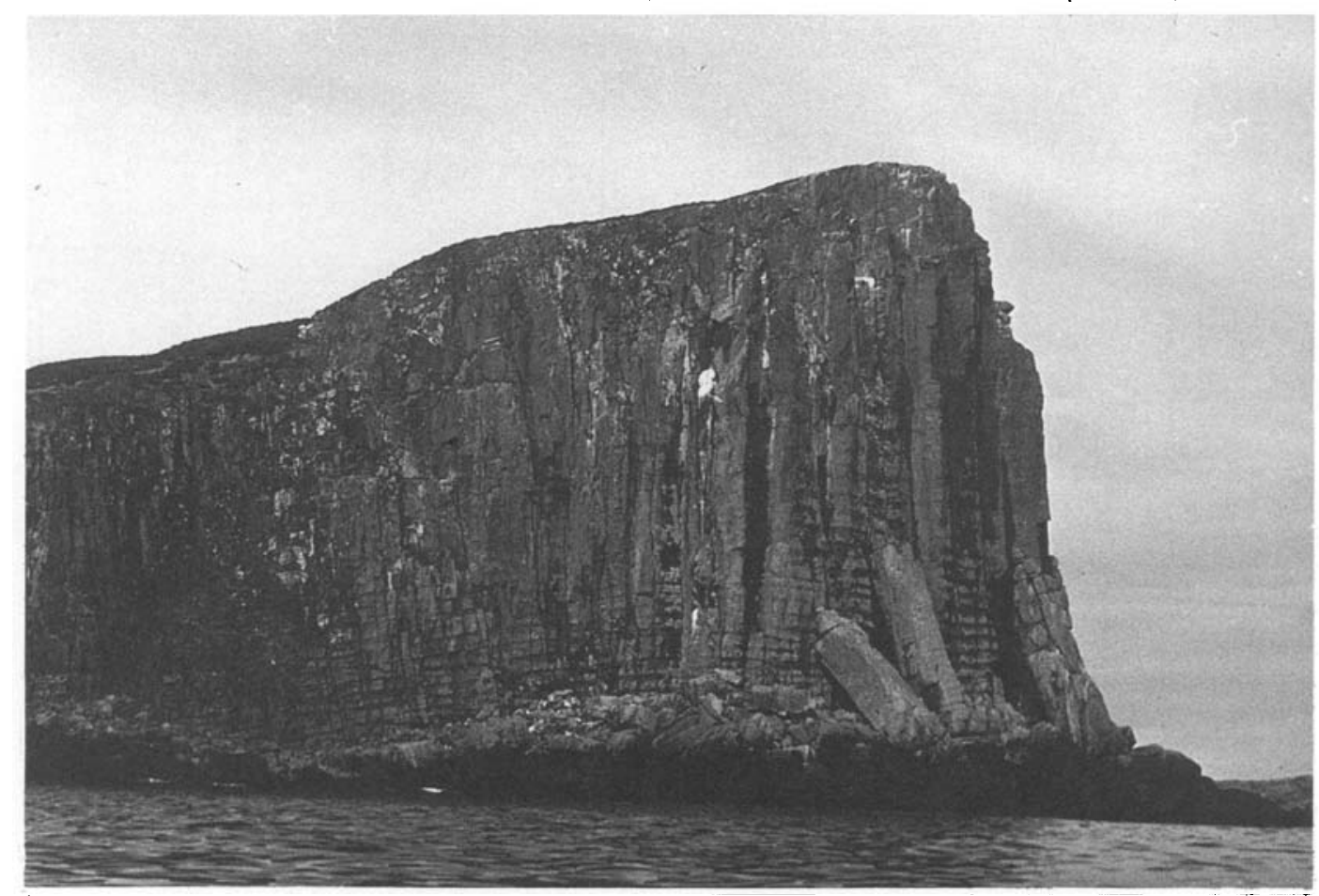

Figure 5. Rhythmic layering in southeast Flodigarry Island. Height of cliffs is approximately $60 \mathrm{~m}$. The base of the sill is at sea level.

and crinanite are also distinguished by textural variations and mineral chemistry (Fig. 7). Representative analyses of mineral compositions are presented in Table 1 and clinopyroxene crystallization trends in Fig. 8.

\section{5.a. Picrites}

The most distinctive feature displayed by the picrites is their very high content of modal olivine (generally $40-60 \%$ ). The olivine occurs as either large (up to $5 \mathrm{~mm}$ in length) euhedral phenocrysts or as slightly smaller subhedral phenocrysts. Occasionally the olivines have re-entrants. The olivine core compositions are almost constant $\left(\mathrm{Fo}_{82}-\mathrm{Fo}_{79}\right)$ with slight $\mathrm{Fe}$ enrichment towards rims (Fig. 7). The olivine is poikilitically enclosed by clinopyroxene $(100(\mathrm{Mg} /$ $\mathrm{Mg}+\mathrm{Fe})=84.1-74.6$ ), which forms $9-24 \%$ of the rock and only rarely occurs as isolated crystals. Plagioclase forms $27-46 \%$ of this lithology; small laths $(<0.5 \mathrm{~mm})$ often occur in aggregates enclosed by the ophitic clinopyroxene, and slightly larger, unenclosed plagioclase phenocrysts (up to $1 \mathrm{~mm}$ ) show normal zonation $\left(\mathrm{An}_{64}-\mathrm{An}_{31}\right)$. In some picrite samples, plagioclase is tangentially arranged around olivine crystals (Fig. 9). Chrome spinel (which is always enclosed by olivine), ilmenite and analcime are present as minor phases $(<2 \%)$.

A local variation of the picrites shows large poikilitic laths of plagioclase $(<6 \mathrm{~mm})$ which sub-enclose olivine. The olivine may have a skeletal appearance and a maximum length of $6 \mathrm{~mm}$. Clinopyroxene is no longer ophitic, but is euhedral/subhedral and sector zoned. Some of the clinopyroxene has a poikilitic relationship with olivine and is itself partially enclosed by plagioclase.

In the picrite sills a distinct textural variation occurs within $5 \mathrm{~m}$ and $10 \mathrm{~m}$ of the lower and upper contacts respectively. In these 'marginal picrites' the olivine content decreases towards the contacts (from $40 \%$ to $7 \%$ ) and is accompanied by a gradual decrease in grain size of the groundmass. At the sill contacts the olivine phenocrysts are euhedral to subhedral, $2 \mathrm{~mm}$ in length with re-entrants and often pseudomorphed by iddingsite (Fig. 10). A few metres away from contacts with sediments, fresh olivine phenocrysts are strikingly zoned $\left(\mathrm{Fo}_{76}-\mathrm{Fo}_{22}\right)$. Plagioclase is also present as a phenocryst phase $(0.5 \mathrm{~mm}$ in length) and shows normal zonation $\left(\mathrm{An}_{67}-\mathrm{An}_{64}\right)$. The plagioclase phenocrysts commonly form open spherulites which are sometimes intergrown with olivine.

Pegmatite veins (up to $1 \mathrm{~m}$ thick) are common within the picrites and are essentially composed of clinopyroxene $(\sim 30 \%)$, plagioclase $(\sim 65 \%)$, ilmenite and zeolites. Olivine is absent. Clinopyroxene is present as either large $(1.5-14.0 \mathrm{~mm}$ in diameter), subhedral phenocrysts or small $(<0.5 \mathrm{~mm})$ acicular crystals in the groundmass. Sector zonation is conspicuous in both generations of clinopyroxene. Some clinopyroxenes, adjacent to alkali-rich mesostases, show extreme Fe-enrichment (Fig. 8) and green aegirine rims. These contain up to $13 \mathrm{wt} \% \mathrm{Na}_{2} \mathrm{O}$ (Table 1) and approximately $6 \mathrm{wt} . \% \mathrm{ZrO}_{2}$ (qualitative analysis). Plagioclase laths are generally less than 


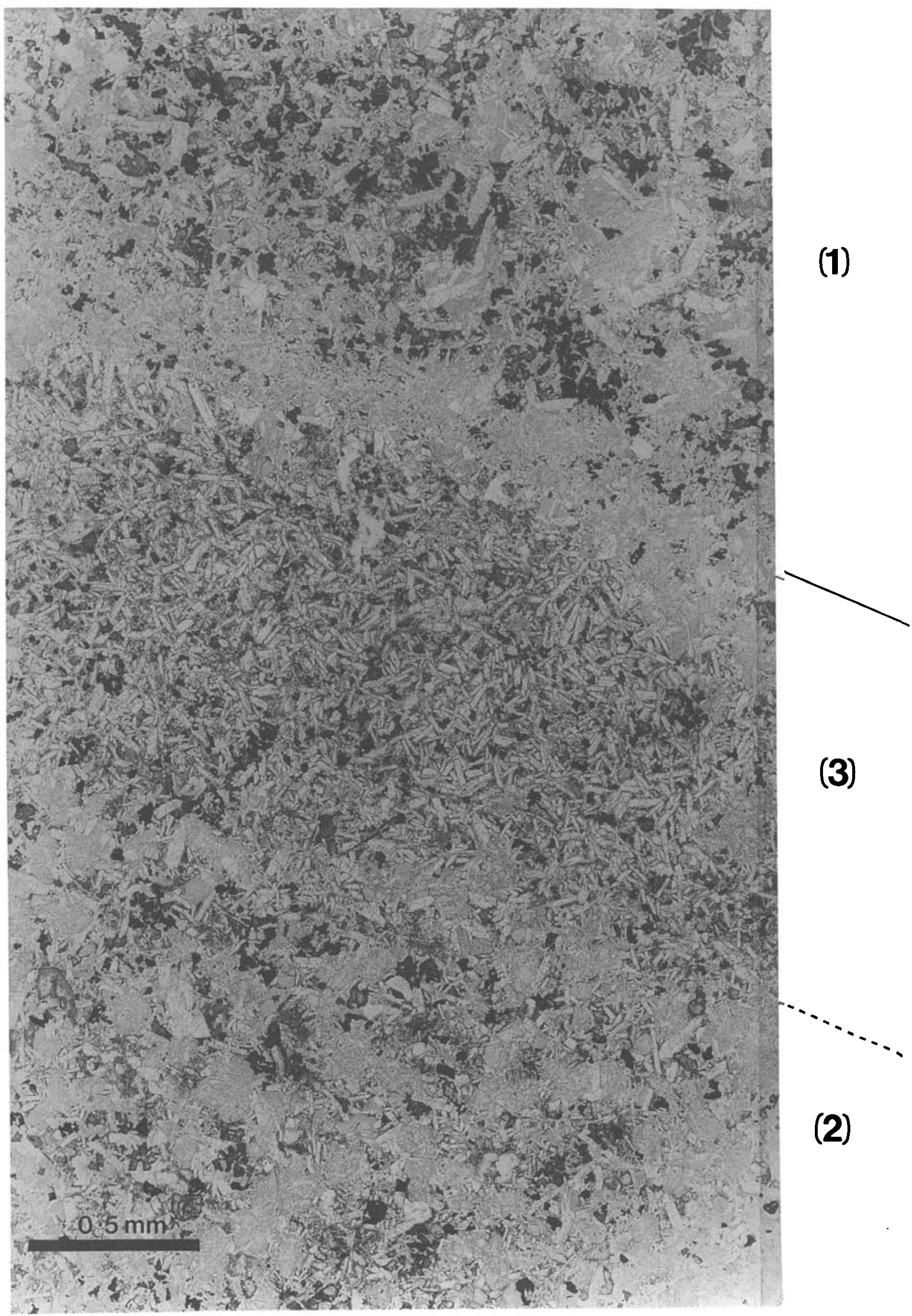

Figure 6. Photomicrograph of rhythmic layering in the Trotternish sills. Most of the olivine is altered to iddingsite and the strongly birefringent mineral is clinopyroxene. (1) is the less resistant olivine-rich horizon which occurs at the base of layers; (2) is a horizon of granular clinopyroxene which overlies (1); and (3) is the resistant feldspathic horizon which is present at the top of layers. 
Table 1. Representative olivine and clinopyroxene compositions

\begin{tabular}{|c|c|c|c|c|c|c|c|c|c|c|}
\hline & & \multicolumn{2}{|c|}{$\begin{array}{l}\text { Picrite } \\
\text { SG114 }\end{array}$} & \multicolumn{2}{|c|}{$\begin{array}{l}\text { Marginal picrite } \\
\text { SG223 }\end{array}$} & \multicolumn{2}{|c|}{$\begin{array}{l}\text { Picrodolerite } \\
\text { SG } 19\end{array}$} & \multicolumn{2}{|c|}{$\begin{array}{c}\text { Crinanite } \\
\text { SG40 }\end{array}$} & \\
\hline & & $\mathrm{OL}(\mathrm{C})$ & $\mathrm{OL}(\mathrm{R})$ & $\mathrm{OL}(\mathrm{C})$ & OL(R) & OL(C) & OL(R) & $\mathrm{OL}(\mathrm{C})$ & $\mathrm{OL}(\mathrm{R})$ & \\
\hline & \multicolumn{10}{|l|}{ Wt. $\%$} \\
\hline & $\mathrm{SiO}_{2}$ & 39.05 & 38.73 & 39.10 & 32.29 & 38.66 & 38.43 & 35.80 & 33.68 & \\
\hline & $\mathrm{Al}_{2} \mathrm{O}_{3}$ & 0.29 & 0.17 & 1.07 & 1.19 & n.d. & n.d. & 0.69 & 1.00 & \\
\hline & $\mathrm{FeO}$ & 16.89 & 20.62 & 20.96 & 52.64 & 24.32 & 25.12 & 34.88 & 45.90 & \\
\hline & $\mathrm{MnO}$ & 0.34 & 0.18 & 0.29 & 1.09 & 0.26 & 0.40 & 0.31 & 0.96 & \\
\hline & $\mathrm{MgO}$ & 42.39 & 39.45 & 38.11 & 10.29 & 35.15 & 34.35 & 25.77 & 15.85 & \\
\hline & $\mathrm{CaO}$ & 0.52 & 0.45 & 0.64 & 0.99 & 0.55 & 0.57 & 0.58 & 0.64 & \\
\hline & $\mathrm{NiO}$ & 0.26 & 0.17 & 0.11 & n.d. & 0.10 & 0.21 & 0.19 & 0.32 & \\
\hline & Total & 99.74 & 99.77 & 100.28 & 98.50 & 99.04 & 99.08 & 98.22 & 98.35 & \\
\hline & \multicolumn{10}{|c|}{ Atoms per 4 oxygens } \\
\hline & $\mathrm{Si}$ & 0.984 & 1.002 & 0.993 & 1.003 & 1.019 & 1.019 & 1.009 & 1.009 & \\
\hline & $\mathrm{Al}$ & 0.006 & 0.003 & 0.021 & 0.044 & 0.000 & 0.000 & 0.023 & 0.035 & \\
\hline & $\mathrm{Fe}$ & 0.984 & 1.002 & 0.445 & 1.368 & 0.553 & 0.557 & 0.821 & 1.149 & \\
\hline & $\mathrm{Mn}$ & 0.005 & 0.003 & 0.004 & 0.029 & 0.003 & 0.009 & 0.007 & 0.024 & \\
\hline & $\mathrm{Mg}$ & 1.592 & 1.554 & 1.443 & 0.477 & 1.379 & 1.359 & 1.083 & 0.707 & \\
\hline & $\mathrm{Ca}$ & 0.009 & 0.008 & 0.011 & 0.033 & 0.015 & 0.016 & 0.017 & 0.021 & \\
\hline & $\mathrm{Ni}$ & 0.003 & 0.003 & 0.002 & 0.000 & 0.002 & 0.002 & 0.005 & 0.007 & \\
\hline & Fo & 82 & 77 & 76 & 26 & 72 & 71 & 38 & 57 & \\
\hline & \multicolumn{2}{|c|}{$\begin{array}{l}\text { Picrite } \\
\text { SG21 }\end{array}$} & \multicolumn{2}{|c|}{$\begin{array}{l}\text { Marginal picrite } \\
\text { SG } 128\end{array}$} & \multicolumn{2}{|c|}{$\begin{array}{l}\text { Pirodolerite } \\
\text { SG251 }\end{array}$} & \multicolumn{2}{|c|}{$\begin{array}{c}\text { Crinanite } \\
\text { SG358 }\end{array}$} & \multicolumn{2}{|c|}{$\begin{array}{l}\text { Pegmatite } \\
\text { SG31 }\end{array}$} \\
\hline & $\mathrm{CPX}(\mathrm{C})$ & $\mathrm{CPX}(\mathrm{R})$ & $\mathrm{CPX}(\mathrm{C})$ & CPX(R) & $\mathrm{CPX}(\mathrm{C})$ & $\mathrm{CPX}(\mathrm{R})$ & $\mathrm{CPX}(\mathrm{C})$ & $\mathrm{CPX}(\mathrm{R})$ & $\mathrm{CPX}(\mathrm{C})$ & $\mathrm{CPX}(\mathrm{R})$ \\
\hline \multicolumn{11}{|l|}{ Wt. \% } \\
\hline $\mathrm{SiO}_{2}$ & 50.11 & 50.45 & 48.21 & 52.36 & 50.51 & 51.35 & 52.85 & 50.34 & 50.67 & 51.82 \\
\hline $\mathrm{Al}_{2} \mathrm{O}_{3}$ & 4.09 & 3.44 & 6.53 & 2.05 & 3.47 & 3.45 & 3.74 & 2.06 & 3.61 & 1.63 \\
\hline $\mathrm{TiO}_{2}$ & 0.55 & 1.95 & 2.09 & 0.53 & 1.15 & 1.49 & 1.00 & 1.00 & 1.68 & 4.24 \\
\hline $\mathrm{FeO}^{2}$ & 5.71 & 7.81 & 8.99 & 14.45 & 7.27 & 10.16 & 6.94 & 15.46 & 7.58 & \\
\hline $\mathrm{Fe}_{2} \mathrm{O}_{3}$ & & & & & & & & & & 23.61 \\
\hline $\mathrm{MnO}$ & 0.13 & 0.16 & 0.26 & 0.48 & 0.18 & 0.32 & 0.16 & 0.29 & 0.28 & 0.27 \\
\hline $\mathrm{MgO}$ & 15.89 & 14.65 & 11.86 & 8.88 & 14.40 & 12.39 & 13.91 & 9.45 & 14.96 & 1.14 \\
\hline $\mathrm{CaO}$ & 20.29 & 19.94 & 21.11 & 21.18 & 20.29 & 20.28 & 20.54 & 18.97 & 19.05 & 3.53 \\
\hline $\mathrm{Na}_{8} \mathrm{O}$ & 1.95 & 1.04 & 1.03 & n.d. & 0.90 & n.d. & 0.83 & 0.73 & 1.91 & $12.0 !$ \\
\hline $\mathrm{Cr}_{2} \mathrm{O}_{3}$ & 1.12 & n.d. & 0.09 & 0.07 & 0.37 & 0.05 & 0.57 & 0.08 & 0.09 & n.d. \\
\hline Total & 99.84 & 99.44 & 100.17 & 100.00 & 98.54 & 99.49 & 100.54 & 98.38 & 99.83 & 98.25 \\
\hline \multicolumn{11}{|c|}{ Atoms per 6 oxygens } \\
\hline $\mathrm{Si}$ & 1.840 & 1.843 & 1.803 & 1.989 & 1.885 & 1.978 & 1.931 & 1.962 & 1.878 & 2.100 \\
\hline $\mathrm{Al}$ & 0.670 & 0.148 & 0.288 & 0.092 & 0.152 & 0.152 & 0.161 & 0.095 & 0.158 & 0.078 \\
\hline $\mathrm{Ti}$ & 0.025 & 0.054 & 0.059 & 0.015 & 0.032 & 0.042 & 0.028 & 0.793 & 0.047 & 0.129 \\
\hline $\mathrm{Fe}^{8+}$ & 0.169 & 0.215 & 0.281 & 0.459 & 0.227 & 0.317 & 0.212 & 0.504 & 0.235 & \\
\hline $\mathrm{Fe}^{3+}$ & & & & & & & & & & 0.953 \\
\hline $\mathrm{Mn}$ & 0.004 & 0.004 & 0.008 & 0.015 & 0.005 & 0.010 & 0.005 & 0.010 & 0.009 & 0.009 \\
\hline $\mathrm{Mg}$ & 0.854 & 0.798 & 0.661 & 0.503 & 0.801 & 0.690 & 0.758 & 0.549 & 0.827 & 0.070 \\
\hline $\mathrm{Ca}$ & 0.800 & 0.780 & 0.846 & 0.862 & 0.811 & 0.811 & 0.805 & 0.793 & 0.757 & 0.155 \\
\hline $\mathrm{Na}$ & 0.058 & 0.074 & 0.074 & 0.000 & 0.090 & 0.000 & 0.059 & 0.080 & 0.137 & 0.936 \\
\hline $\mathrm{Cr}$ & 0.029 & 0.000 & 0.060 & 0.002 & 0.011 & 0.007 & 0.016 & 0.002 & 0.003 & 0.000 \\
\hline
\end{tabular}

Analyses of mineral chemistry were measured on a JEOL T300 SEM and Link system 860 probe. Abbreviations: OL, olivine; CPX, clinopyroxene; R, rim; C, core; n.d., not detected.

$4 \mathrm{~mm}$ in length and are strongly zoned. Zeolites (usually thomsonite) 'occur as spectacular radiating fibrous aggregates (up to $1.5 \mathrm{~mm}$ in diameter) and form a maximum of $5 \%$ of this lithology. The pegmatite veins have a gradational lower contact and a sharp upper contact with the surrounding picrite. The picrite shows an upward increase in modal plagioclase and clinopyroxene towards the base of the pegmatite veins but no evidence of chilling.

\section{5.b. Picrodolerites}

Picrodolerites are distinguished from picrites by their lower content of modal olivine (10-20\%). The greatest amount of olivine occurs adjacent to the picrite/ picrodolerite junction and decreases gradually into the crinanites. This decrease is compensated by an increase in clinopyroxene which becomes increasingly ophitic with plagioclase. Olivine in the picrodolerites is subhedral/anhedral and shows a greater $\mathrm{Fe}$ enrichment $\left(\mathrm{Fo}_{73}-\mathrm{Fo}_{76}\right)$ than has been observed in the 


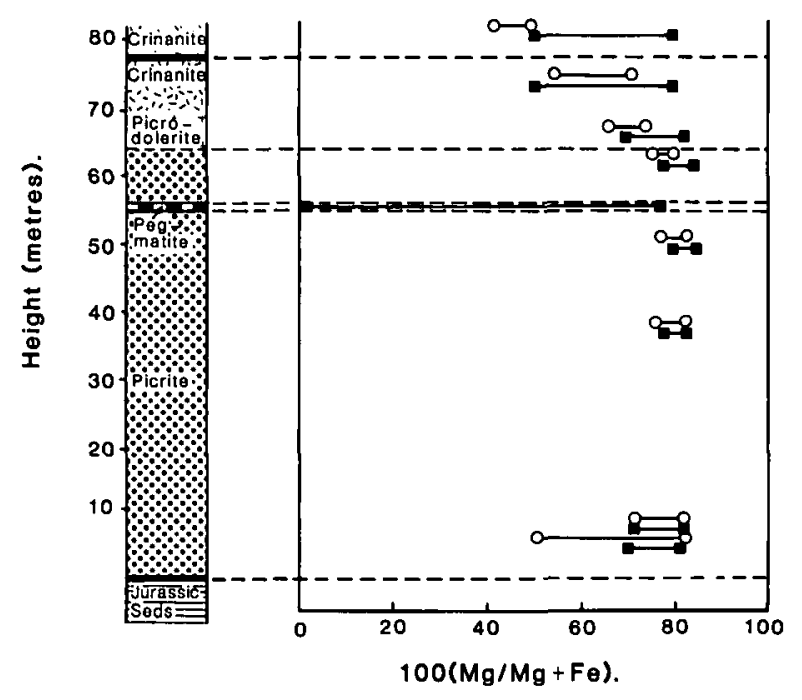

Figure 7. Variations in mineral composition with height and lithology in the northwest Trotternish sill. Symbols are as follows: $O$ olivine and $\mathbf{D}$ clinopyroxene. picrites. Glomerophyric aggregates of olivine and clinopyroxene $(100(\mathrm{Mg} / \mathrm{Mg}+\mathrm{Fe})=83.2-43.9)$, 3$4 \mathrm{~mm}$ in diameter, are common in the picrodolerites and typically consist of a large olivine crystal $(2 \mathrm{~mm})$ surrounded by smaller $(0.5 \mathrm{~mm})$ granular clinopyroxene crystals. A few larger clinopyroxene crystals $(1.5 \mathrm{~mm})$ subophitically enclose plagioclase. Plagioclase laths $(<1.5 \mathrm{~mm})$ exhibit strong normal zonation $\left(\mathrm{An}_{65}-\mathrm{An}_{18}\right)$ and form $50-60 \%$ of this lithology. They have a subophitic relationship with ilmenite ( $<1 \mathrm{~mm}$ ).

\section{5.c. Crinanites}

The crinanites have an essential mineralogy of clinopyroxene $(25-40 \%)$, plagioclase $(55-65 \%)$ and analcime $(<3 \%)$ and, in comparison with the picrites and picrodolerites, are olivine-poor $(<5 \%)$. The olivine $\left(\mathrm{Fo}_{81}-\mathrm{Fo}_{38}\right)$ is anhedral, up to $3.5 \mathrm{~mm}$ in diameter and sub-encloses plagioclase. Phenocrysts in
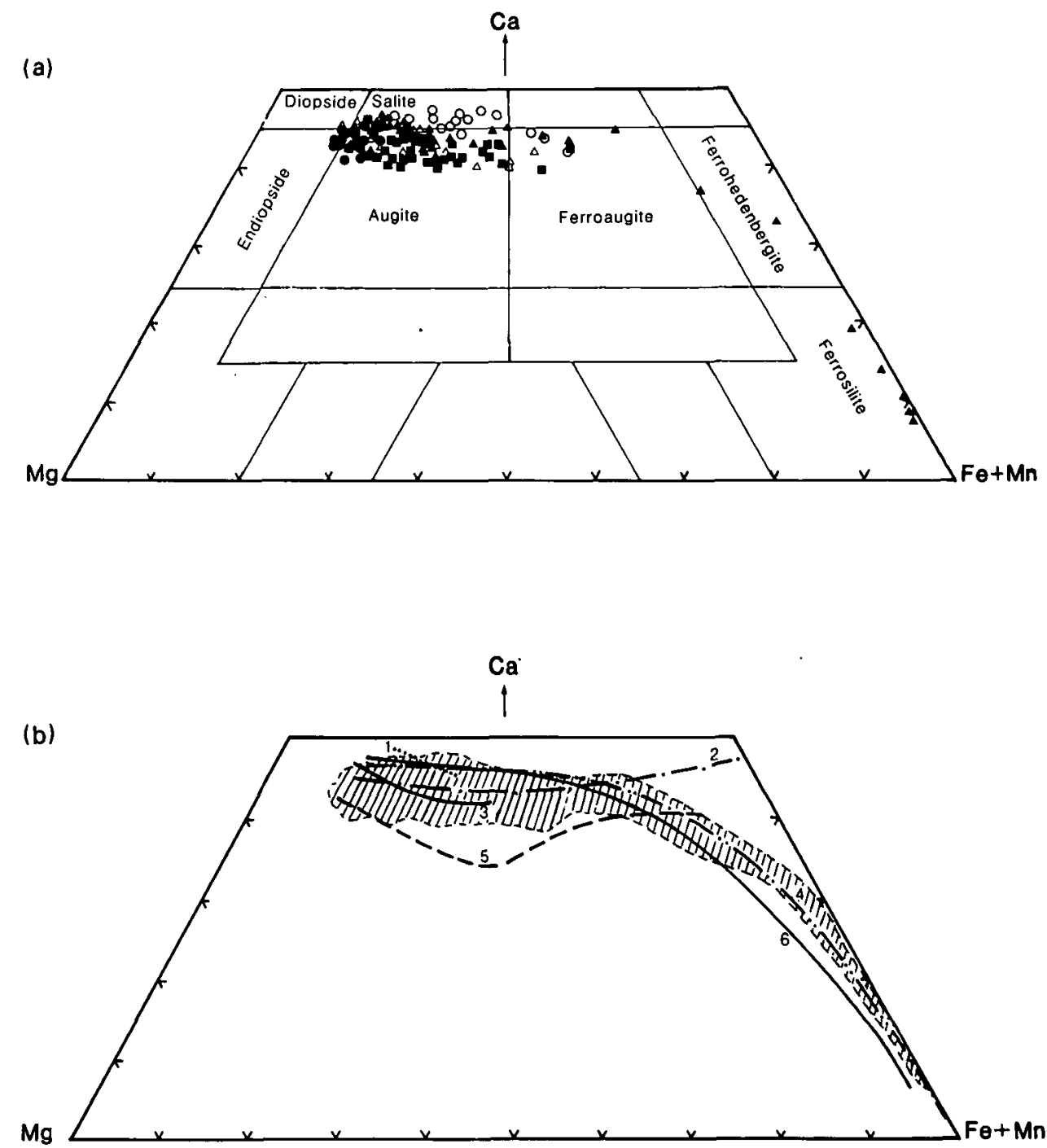

Figure 8. (a) Variations in clinopyroxene compositions in the Trotternish sills. Symbols are as follows picrite; $O$ marginal picrite; $\triangle$ picrodolerite; $\square$ crinanite; $\Delta$ pegmatite. (b) Comparison between the observed trend (shaded area) with other wellknown intrusions (1) Black Jack sill (Wilkinson, 1957); (2) Main Shiant Isles sill (Gibb, 1973); (3) Main Shiant Isles sill (Murray, 1954); (4) Eilean Mhuire sill, Shiant Isles (A. R. O. Mohammed, unpub. Ph.D. thesis, Univ. Oxford, 1982); (5) Skaergaard Intrusion (Wager \& Brown, 1967); (6) Shonkin Sag laccolith (Nash \& Wilkinson, 1970). 


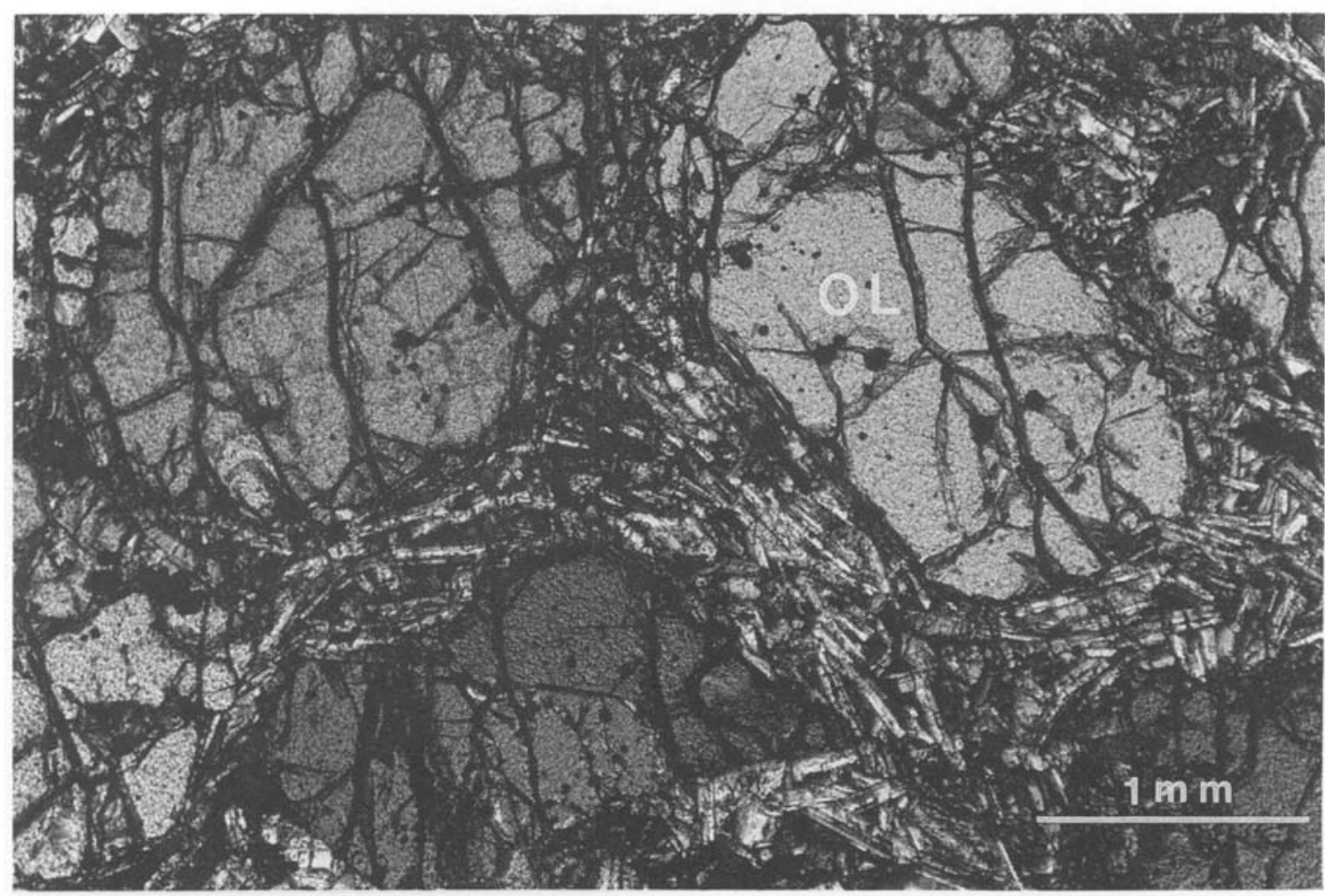

Figure 9. Plagioclase laths tangentially arranged around olivine in a picrite sample.

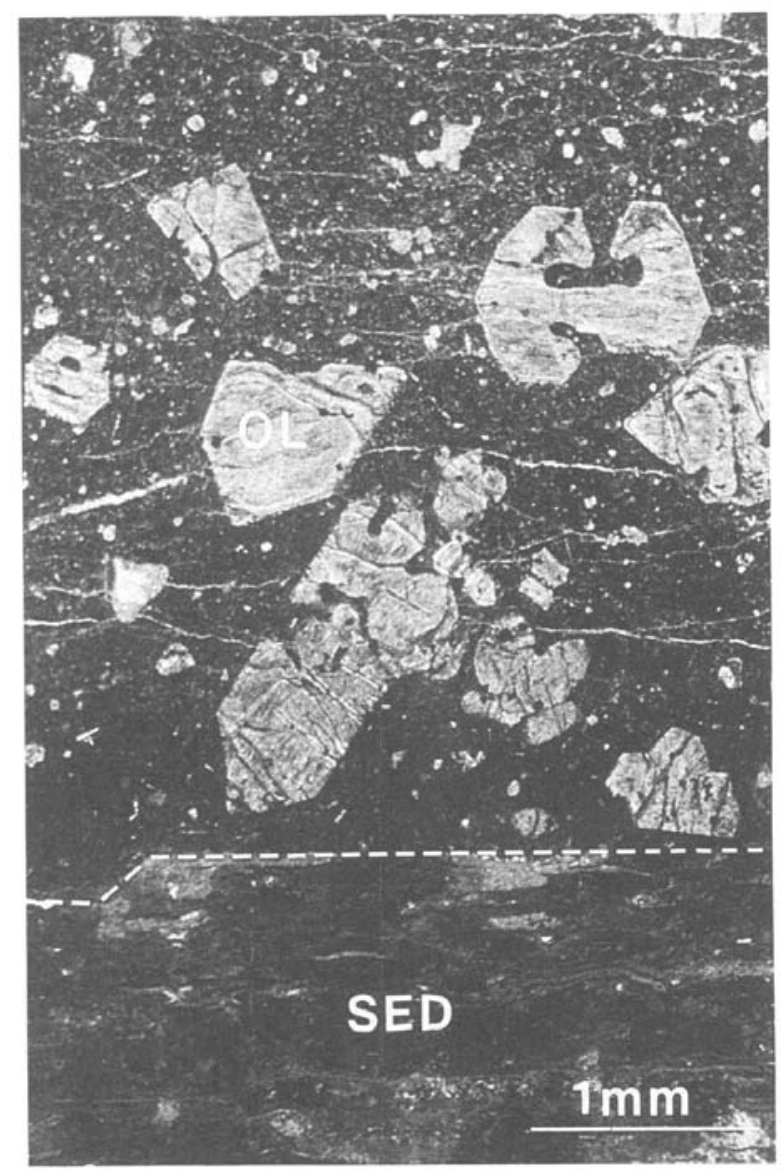

Figure 10. Photomicrograph showing euhedral olivine phenocrysts (altered to iddingsite) in the chilled margin at the lower sill/sediment contact, Osmigarry. the chilled margins are euhedral and comparable in composition with picritic olivines $\left(\mathrm{Fo}_{81}-\mathrm{Fo}_{79}\right)$. They become more $\mathrm{Fe}$-rich away from the chilled margins. Large clinopyroxene crystals (up to $5 \mathrm{~mm}$ in length) are strongly zoned $\left(\mathrm{Mg}_{72.7}-\mathrm{Mg}_{51.0}\right)$ and ophitically enclose small plagioclase laths $(<1.5 \mathrm{~mm})$. Unenclosed plagioclase laths $(<2.5 \mathrm{~mm})$ sometimes occur as open spherulites. Large titaniferous magnetite crystals (up to $2 \mathrm{~mm}$ ) are common (up to 5 modal \%) and are intergrown with plagioclase. Analcime occurs interstitially in cavities with thomsonite.

A few pegmatite veins occur in the crinanites. A thick $(\sim 1 \mathrm{~m})$ pegmatite vein is present two-thirds above the base of the crinanite sill ( $36 \mathrm{~m}$ thick) at Staffin [NG 494 680]. These pegmatites generally consist of plagioclase $(65 \%)$, granular clinopyroxene $(15 \%)$, anhedral olivine $(15 \%)$ and opaque oxides $(5 \%)$.

\section{Interpretations of petrography}

Poikilitic textures in the picrites resemble those of other well-known cumulate intrusions such as Skaergaard. Textures relating to adcumulus growth do not occur in the picrites and indicate that the rate of solidification exceeded the rate of convection (Sparks et al. 1985). The elongate crystals of plagioclase and olivine in the 'big feldspar picrite' may imply rapid crystallization and be analogous with undercooling along the synthetic forsterite-plagioclase cotectic. Donaldson (1976) crystallized olivines resembling those in the marginal picrites and suggested that they 
are the result of either rapid cooling $\left(50^{\circ} \mathrm{C} /\right.$ hour $)$ and undercooling $\left(T^{\circ} \mathrm{C}=40\right)$ or rapid growth due to a large olivine content in the melt. Previously, Drever \& Johnston (1957) suggested that re-entrants in the shapes of these olivines were evidence of resorption. The proximity of such olivines to the margins of the sills suggests that the re-entrants are the result of rapid cooling. The significant Fe-enrichment at the rims of olivines in the marginal picrites may be interpreted in terms of changing thermal and chemical gradients surrounding the olivine phenocrysts. Rapid cooling close to the contacts would inhibit total re-equilibration and homogenization of the olivine. The presence of spinel, olivine and plagioclase phenocrysts in the chilled margins of the picrites implies that they were all near-liquidus phases in the magma at the time of emplacement.

Interlocking relationships between the pegmatite veins and surrounding picrite suggest that the formation of the veins is contemporaneous with crystallization of the picrite. The increasing amount of modal plagioclase and decreasing modal olivine within the host picrite towards the base of the veins suggests that the veins may have been derived by filter-press action. This mechanism involves the post-cumulus movement of interstitial liquid, as a result of compaction in the cumulus pile due to density differences between olivine and plagioclase. Interstitial liquid expelled upwards from the cumulus pile during compaction may have accumulated locally as veins. The relatively thin veins may have coalesced to form much thicker ones, such as the $75 \mathrm{~cm}$ thick pegmatite vein at $\mathrm{Ru}$ Bornaskitaig [NG 370 729]. This pegmatite occurs close to the upper contact of the picrite sill, possibly at the boundary of the upper and lower crystallization fronts. In this zone the expelled liquid may have ponded beneath a relatively impervious layer, but in an area favouring freedom of nucleation and crystal growth. The presence of plagioclase laths tangentially arranged around olivines in the picrites (Fig. 9) may reflect this compaction. Similar compaction textures have been observed in the Eastern Layered Series of Rhum (Young \& Donaldson, 1985). The decrease in modal olivine towards the top of some picrite sills, such as the one at Skudiburgh [NG 374 674], may also be due to compaction. Swallow-tail terminations in clinopyroxenes imply undercooling, rapid crystallization and supersaturation, whilst biotite and zeolites infilling drusy cavities suggest an increase in water saturation during the later crystallization stages of the pegmatite veins. The absence of amphibole may reflect a deficiency of $\mathrm{K}_{2} \mathrm{O}$ or low temperatures.

The glomerophyric clusters of clinopyroxene surrounding olivine that occur in the picrodolerites resemble reaction textures. Similar textures occur in Hawaiian tholeiites, where olivine is mantled by a rim of orthopyroxene, formed by reaction with surround- ing silica-rich liquid (BVSP, 1981). In the multiple sills of northwest Trotternish the olivine crystals in the picrodolerites may be cognate xenocrysts from the underlying picrite which have been incorporated into, and reacted with, the more silica-rich magma of the picrodolerites to form clinopyroxene. Such 'xenocrysts' are present up to $5 \mathrm{~m}$ above the picrite/ picrodolerite contact and may suggest significant mixing and relatively rapid cooling in order to prevent the olivine from complete reaction with the surrounding 'silica-rich' magma. Clinopyroxene supersaturation and the cooling rate appear to have been lower in the picrodolerites than in the crinanites so that the growth/nucleation rate was relatively high and zoned ophitic clinopyroxene crystallized.

\section{Geochemical variations in igneous stratigraphy}

Stratigraphical variations in major and trace elements are shown in a composite profile from the sills in northwest Trotternish (Fig. 11). Representative wholerock analyses are presented in Table 2. All elements have relatively constant concentrations within the picrite unit, with marked variations occurring at the marginal picrite/picrite transition and at the picrite/ picrodolerite junction. Both changes reflect, primarily, a sharp decrease in modal olivine. Interaction at the sill margins with Jurassic sediments produces increases in $\mathrm{CaO}, \mathrm{MnO}$ and $\mathrm{Sr}$ contents and the scatter of element concentrations. The gradual petrographic transition from picrodolerites to crinanites shows corresponding changes in geochemistry. The highest concentrations of $\mathrm{MgO}$ (30 wt. \%) occur in the centre of the picrite unit, gradually decreasing outwards, towards the picrite/picrodolerite and marginal picrite/picrite transition, comparable to variations in modal olivine. The lowest concentrations of $\mathrm{MgO}$ occur in the crinanites $(<7.5 \mathrm{wt} . \%)$ which are structurally highest in the stratigraphy. $\mathrm{FeO}^{\mathrm{T}}$ $\left(=\mathrm{FeO}+\mathrm{Fe}_{2} \mathrm{O}_{3}\right.$ ) and $\mathrm{MnO}$ exhibit similar variations to $\mathrm{MgO}$. This correlation between $\mathrm{MgO}$ and $\mathrm{FeO}^{\mathrm{T}}$ relates to the modal distribution of chrome spinels and olivine. The cumulative concentration of $\mathrm{FeO}^{\mathrm{T}}$ in both of these minerals is responsible for the high $\mathrm{FeO}^{\mathrm{T}}$ $(13 \%)$ in picrites. Other major elements show an antipathetic relationship to this trend.

The inverse relationship between $\mathrm{MgO}$ and $\mathrm{CaO}$ suggests that clinopyroxene has had little influence on $\mathrm{MgO}$ concentrations. Increases in $\mathrm{TiO}_{2}$ (from $0.5 \%$ to $2.7 \%$ ) with height in the sill reflect the increasing modal amounts of ilmenite in picrodolerites and titaniferous magnetite in crinanites. Trace element concentrations parallel the major element variations and highlight the contrasting trends. Concentrations of $\mathrm{Cr}$ and $\mathrm{Ni}$ vary uniformly with $\mathrm{MgO}$. A two-fold jump in Sc (from $20 \mathrm{ppm}$ to $42 \mathrm{ppm}$, at Creagan Iar; Fig. 2) at the picrite/picrodolerite junction reflects a similar two-fold increase in modal clinopyroxene. 


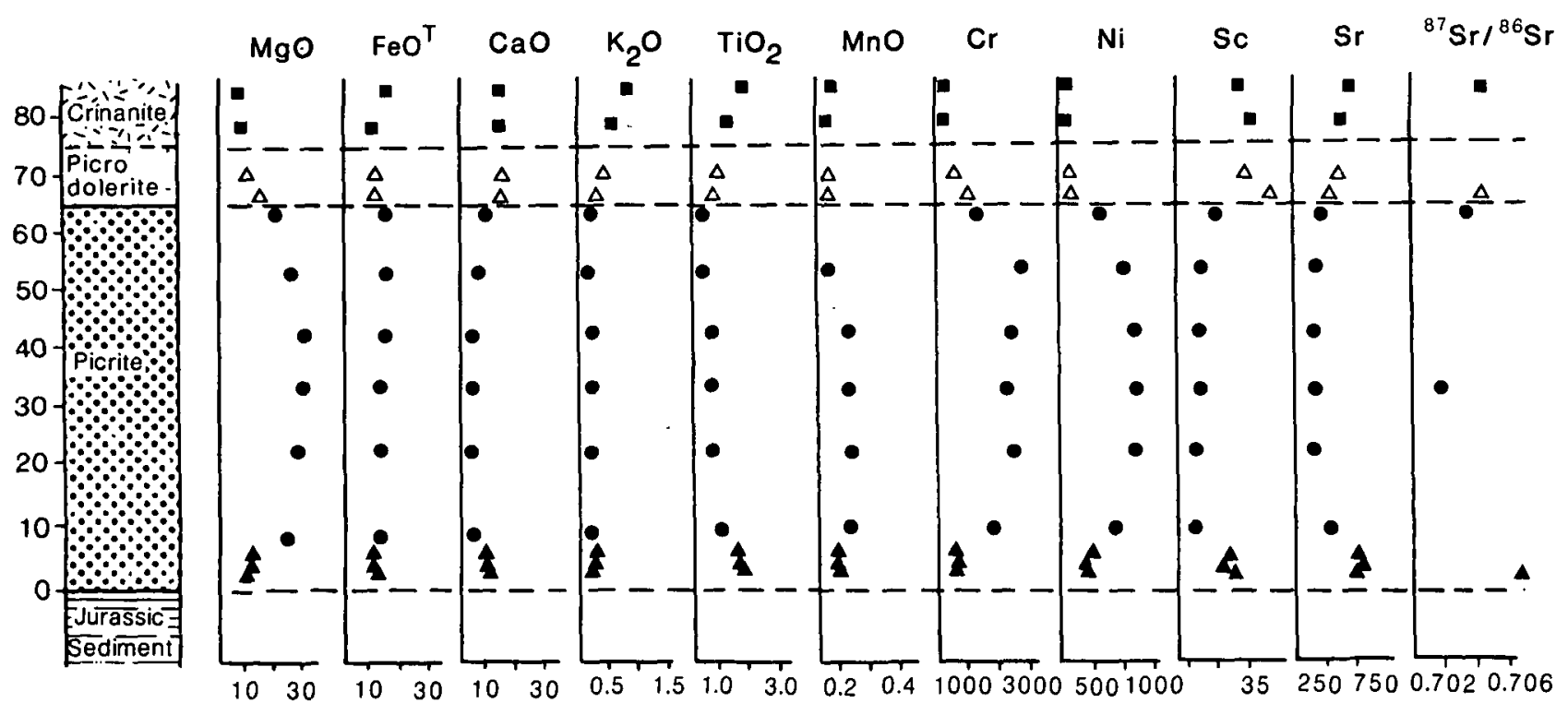

Figure 11. Stratigraphic variations in major and trace elements in the northwest Trotternish sill. Symbols are as follows:

- picrite; $\Delta$ marginal picrite; $\triangle$ picrodolerite; $\boldsymbol{\square}$ crinanite.

Table 2. Representative major, trace and rare-earth element analyses and isotope ratios for the Trotternish sills

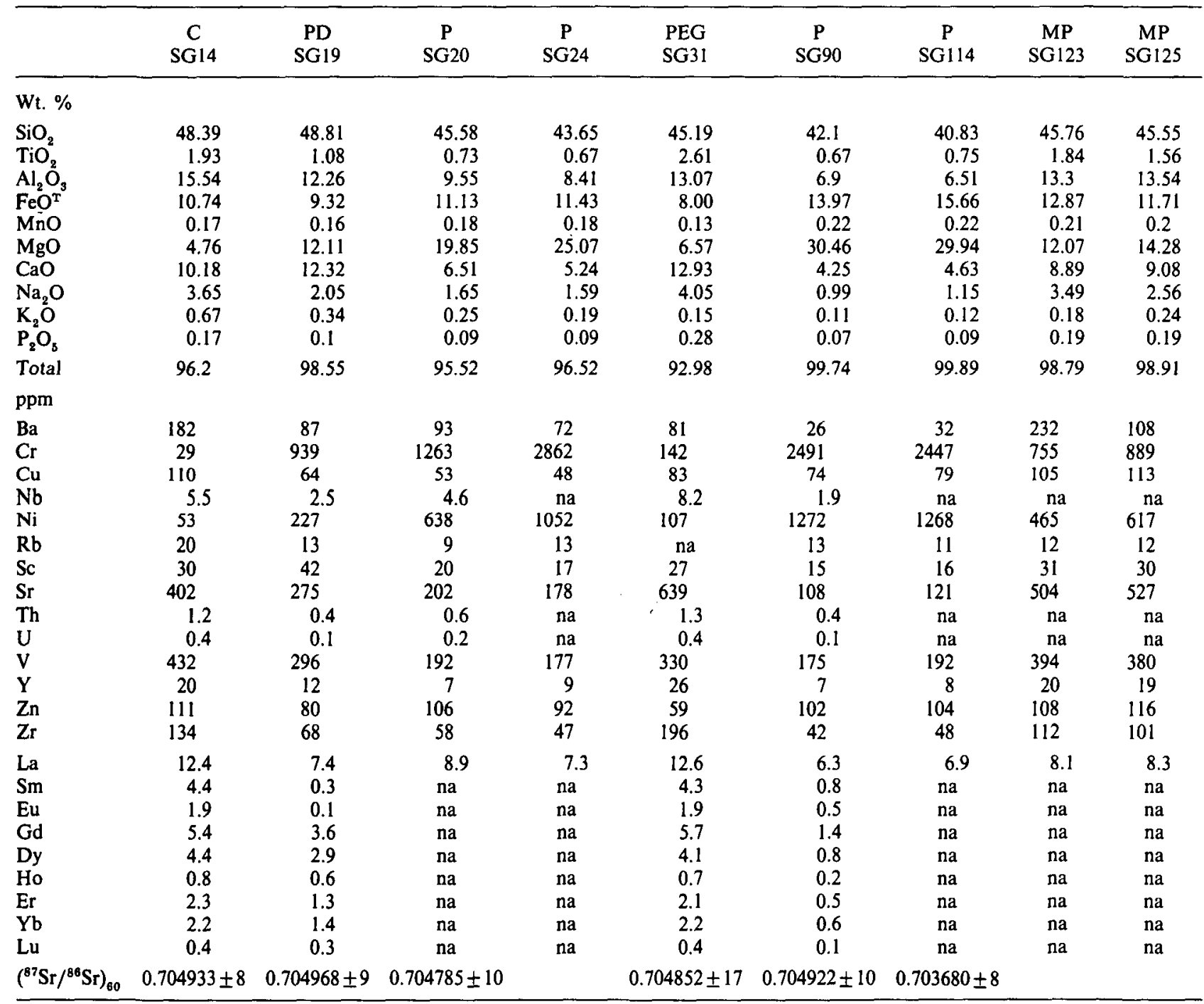

All major and trace elements except $\mathrm{Nb}$ were determined by ICP AES. Nb was analysed by ICP MS. Isotope ratios were determined on a VG 354 thermal ionisation mass spectrometer for which SRM gave $0.710241 \pm 8$. Abbreviations: C, crinanite; PD, picrodolerite; P, picrite; PEG, pegmatite; MP, marginal picrite; na, not analysed. 
${ }^{87} \mathrm{Sr} /{ }^{86} \mathrm{Sr}$ ratios have been obtained for 9 representative samples, from the Trotternish sills and a syenite from Eilean Mhuire, Shiant Isles. The results of these determinations are as follows: ${ }^{87} \mathrm{Sr} /{ }^{86} \mathrm{Sr}$ ratios range from 0.70360 to 0.70479 in picrites, 0.70492 to 0.70497 in picrodolerites and 0.70493 to 0.70531 in crinanites. They have a negative correlation with $\mathrm{MgO}$ (Fig. 11). The variation in $\mathrm{Sr}$ isotopes with petrography is consistent with major and trace element variations and suggests the picrites, picrodolerites and crinanites are genetically related. The syenite from Eilean Mhuire, Shiant Isles and a pegmatite vein from Bornaskitaig (SG31) have very low ${ }^{87} \mathrm{Sr} /{ }^{86} \mathrm{Sr}$ ratios (0.70432 and 0.70485 respectively) considering their highly evolved petrography. The similar low ${ }^{87} \mathrm{Sr} /{ }^{86} \mathrm{Sr}$ ratio of the Eilean Mhuire syenite and the pegmatite vein are compatible with a direct relationship with the picrites, probably by filter pressing (S. A. Gibson, unpub. Ph.D. thesis, Kingston Polytechnic, 1988). Previously, Walker (1930) suggested that the syenites formed by auto-intrusion and A. R. O. Mohammed (unpub. Ph.D. thesis, Univ. Oxford, 1982) suggested that the syenites may be the result of an upward migration of volatiles.

\section{Parental magma}

The whole-rock chemistry of chilled margins is often used to estimate parental magma compositions of plutons. Phenocrysts of olivine and plagioclase in the chilled margins of the Trotternish sills suggest that the magma had started fractionating prior to sill emplacement and these chilled margins may only approximate to liquid compositions. However, samples from picritic chilled margins (SG61, SG88, SG254) have whole-rock compositions which are in equilibrium with olivine $\mathrm{Fo}_{82}-\mathrm{Fo}_{84}$ (calculated from Roeder \& Emslie, 1970). Frey, Green \& Roy (1978) suggested that primary basic magmas derived by partial melting of upper mantle peridotite should have
$\mathrm{Mg} /(\mathrm{Mg}+\mathrm{Fe})$ ratios between 68 and 75 . All of the chilled margins have $\mathrm{Mg}$ values which are lower than this and are too evolved to be a partial melt of normal upper mantle peridotite. This may be explained by one or all of the following processes:

(i) The parental magma of the Trotternish sills may have undergone crystal fractionation at the base of the crust, prior to emplacement in the magma chamber. Fractionation of olivine and/or clinopyroxene would decrease the $\mathrm{Mg} /(\mathrm{Mg}+\mathrm{Fe})$ ratio of the magma.

(ii) Highly forsteritic olivine may have fractionated and accumulated at the base of the magma chamber where it remains hidden.

(iii) The olivines $\left(\mathrm{Fo}_{83}\right)$ in the sills may represent sub-solidus re-equilibrated compositions.

Overall variations in whole-rock geochemistry suggest that crystal fractionation and accumulation were important processes during magma evolution. This fractionation and accumulation have been modelled using a least-squares computer program based on that of Bryan, Finger \& Chayes (1969) and a parental magma with the same composition as SG254 (Table 3). Analysed minerals were used to estimate the compositions of the fractionating phases. Although the calculations assume that mineral compositions are constant, which may be petrologically unrealistic, the results (Table 3) show similarities with petrographic interpretations. The most $\mathrm{MgO}$-rich picrites such as SG90 (30.46 wt.\%) are calculated to have $62 \%$ olvine $\left(\mathrm{Fo}_{83}\right), 2.9 \%$ plagioclase and $1.2 \%$ chrome spinel. Clinopyroxene is an insignificant cumulus phase in the calculations.

The differentiation of a parental magma with the same composition as SG254 to MgO-poor crinanites such as SG14 (4.92 wt.\%) has also been modelled (Table 3). Plagioclase $\left(\mathrm{An}_{80}\right)$ may have been an important fractionating phase $(32 \%)$ in addition to olivine $\left(\mathrm{Fo}_{83} ; 14.6 \%\right)$, clinopyroxene $(9.4 \%)$ and titaniferous magnetite $(6.4 \%)$. The picrodolerites may

Table 3. Least squares computer modelling of crystal fractionation and accumulation in the Trotternish sills

\begin{tabular}{|c|c|c|c|c|}
\hline & \multicolumn{2}{|c|}{$\begin{array}{c}\text { Model } 1 \\
\text { SG254 }+ \text { OL }+ \text { SP }+ \text { PL } \\
\rightarrow \text { SG } 90\end{array}$} & \multicolumn{2}{|c|}{$\begin{array}{c}\text { Model } 2 \\
\text { SG254 } \rightarrow \text { SG14 }\end{array}$} \\
\hline Parent liquid or accumulate & \multicolumn{2}{|c|}{ SG90 } & \multicolumn{2}{|c|}{ SG254 } \\
\hline Olivine & $\mathrm{Fo}_{83}$ & $62.0 \%$ & $\mathrm{Fo}_{83}$ & $14.6 \%$ \\
\hline Clinopyroxene & & - & $\mathrm{C}_{39} \mathrm{M}_{50} \mathrm{~F}_{11}$ & $9.4 \%$ \\
\hline Plagioclase & $\mathrm{An}_{80}$ & $2.9 \%$ & $\mathrm{An}_{80}$ & $32.8 \%$ \\
\hline Fe-oxide & $\mathrm{Sp}^{\circ 0}$ & $1.2 \%$ & $\mathrm{Mgt}$ & $6.4 \%$ \\
\hline $\begin{array}{l}\text { Residual liquid or liquid } \\
\text { fraction of cumulate }\end{array}$ & SG254 & $33.9 \%$ & SG14 & $36.8 \%$ \\
\hline$\Sigma \mathrm{R}^{2}$ & & 0.997 & & 0.883 \\
\hline
\end{tabular}

Model 1 demonstrates the crystal accumulation of a picrite (SG90) from the proposed parental magma (SG254). Model 2 shows the degree of crystal fractionation required to form a crinanite (SG14) from SG254. $\Sigma R^{2}$ is the sum of squares for oxide percentage differences between observed and calculated compositions $\left(\Sigma \mathrm{R}^{2}<\mathrm{I}\right.$ are considered to be significant). Abbreviations: OL, olivine; SP, Sp, spinel; PL, plagioclase; Fo, forsterite; An, anorthite; Mgt, magnetite. 
represent the accumulation of these fractionated phases.

\section{Emplacement models}

\section{9.a. Previous emplacement models}

In the first major petrographic study of the LMSC Walker (1930) accounted for the basal concentration of olivine in the main Shiant Isles sill, by in situ gravitational differentiation of crinanitic magma, due to olivine sinking and filter-pressing. However, Walker (1932) suggested that large-scale differentiation in inter-crustal reservoirs, prior to the intrusion of at least two separate pulses of magma, is necessary to explain the considerable volume of picrite in the Trotternish sills. Drever \& Johnston (1959) suggested, with the discovery of the picrite/picrodolerite discontinuity in the Main Shiant Isles sill, that the picrite was emplaced as a separate intrusion to the rest of the sill. Simkin (unpub. Ph.D. thesis, Univ. Princeton, 1965; Simkin, 1967) examined variations in modal mineralogy within the sills in northwest Trotternish and concluded that they were emplaced by flow differentiation. Gibb (1973) proposed a mechanistic emplacement model for the Shiant Isles, expanding on the ideas of Drever (1953) and Drever \& Johnston $(1959,1965,1967)$. He envisaged the continuous emplacement of the picrite unit as a 'dense plug of olivine-rich sludge', after emplacement of the crinanite. Following the discovery of an upper picrite unit in the main Shiant Isles sill, Gibb \& Henderson (1989) suggested that the main Shiant Isles sill was emplaced by multiple intrusion of picrite followed by crinanite.

\section{9.b. Proposed emplacement model}

The following petrographic and geochemical evidence suggests that the Trotternish sills were emplaced as a series of multiple intrusions with subsequent in situ differentiation:

(i) the presence of internal chills;

(ii) sills composed of single and multiple lithologies;

(iii) abrupt changes in petrographic textures and mineral compositions at the picrite/picrodolerite junction.

Huppert \& Sparks (1989) have described how chilled margins in sills may be partially or totally remelted and how internal contacts may result from a single intrusive episode. They suggested that the amount of remelting should be highly asymmetric due to convection resulting in high heat flux at the roof. However, Gibb \& Henderson (1989) dismissed a model involving a single flux of magma and remelting to explain the picrite/picrodolerite contact in the main Shiant Isles sill due to the distance from the lower and upper sill/sediment contacts.

Multiple intrusion may have resulted from withdrawal of magma from either interconnecting discrete magma chambers or from different levels in a single compositionally zoned magma chamber. Several factors suggest that the LMSC was emplaced by multiple intrusion from a single compositionally zoned magma chamber:

(i) The similar chemical compositions of olivine phenocrysts $\left(\mathrm{Fo}_{82}\right)$ in both the crinanite and picrite chilled margins indicate that a common source of olivine was available, prior to emplacement.

(ii) Continuous and systematic variations in mineral chemistry, whole-rock composition, $\mathrm{Sr}$ isotope ratios and petrographic textures with stratigraphic height (Gibson, 1990) suggest the tapping and subsequent emplacement from a single, compositionally zoned magma chamber.

Field relationships are not so simple, and a more complex emplacement mechanism is required for the LMSC than sequential withdrawal of less-fractionated magmas from progressively deeper levels in a zoned reservoir. At Invertote, east Trotternish, the picrite appears to have been emplaced before the overlying crinanite. The presence of strongly zoned olivine in the picrite directly below the contact suggests that the crinanite unit was emplaced close to the upper contact of the picrite unit. Nevertheless, the chill at the base of the crinanite unit suggests that the picrite had sufficient time to cool to a lower temperature than the crinanite magma. At Invertote, columnar jointing is continuous across the picrite/crinanite chill, which indicates that the sill eventually cooled as a single unit. At the picrite/picrodolerite junction in northwest Trotternish there is no evidence of chilling but the glomerophyric clusters of olivine and clinopyroxene in the picrodolerites resemble xenocrysts.

The emplacement of the Trotternish sills appears to have taken place discontinuously and may relate to intervals during withdrawal of magma from the chamber. Murata \& Richter (1976) observed a correlation between discharge rate and olivine content in the 1959 Kilauean eruptions; at high discharge rates olivine-rich magmas (containing up to $50 \%$ olivine phenocrysts) were erupted. The olivine distribution in the Trotternish sills suggests that the discharge rates were relatively high during the initial stages of magma withdrawal and olivine-rich magma was tapped from low levels in the chamber. A decrease in discharge rates and/or the outlet width (Blake \& Ivey, 1986), would result in the withdrawal of crinanitic magma from the upper regions of the chamber. This olivine-poor magma was emplaced as homogenous sills, such as Staffin, or formed the upper parts of multiple intrusions, such as in northwest Trotternish. Sr isotope ratios show a continuous correlation with whole-rock geochemistry and provide no evidence of successive magma replenishment. The increase in modal olivine away from the contacts of picrite sills suggests that flowage differentiation may have been a significant process at the margins. The 
effects of this process away from the contacts in thick intrusions $(>10 \mathrm{~m})$ is limited by grain dispersive pressure (Barrière, 1976).

\section{Conclusions}

Variations in petrography, major and trace elements, and $\mathrm{Sr}$ isotopes with igneous stratigraphy suggest that the picrites, picrodolerites and crinanites in the Trotternish sills are genetically related and result from the multiple intrusion of magma from a compositionally zoned chamber in the upper crust. Picrites (18-30 wt.\% $\mathrm{MgO}$ ) may be interpreted as olivine cumulates, and crinanites (3-8 wt. \% $\mathrm{MgO}$ ) as olivinepoor fractionates of an alkali olivine basalt (10 wt.\% $\mathrm{MgO}$ ) parental magma. Pegmatite veins and the olivine distribution in picrites are evidence of postemplacement compaction. Rhythmic layering at sill contacts may be the result of variable growth/ nucleation ratios at the forsterite-diopside-anorthite eutectic in response to undercooling.

Acknowledgements. Sally Gibson acknowledges financial support from a Research Assistantship at Kingston Polytechnic. Technical assistance with electron microprobe (Kingston Polytechnic), whole-rock analyses (City of London Polytechnic) and radiogenic isotopes (Royal Holloway and Bedford New College) is also gratefully acknowledged. C. H. Emeleus and R. N. Thompson are thanked for their constructive criticisms on an earlier draft of this paper.

\section{References}

Anderson, F. W. \& Dunham, K. C. 1966. The Geology of Northern Skye. Memoirs of the Geological Survey.

BARRIERE, M. 1976. Flowage differentiation: limitation of the 'Bagnold effect' to narrow intrusions. Contributions to Mineralogy and Petrology 55, 139-45.

BeLl, B. R. \& HARRIS, J. W. 1986. An Excursion Guide to the Geology of the Isle of Skye. Geological Society of Glasgow.

Blake, S. \& IveY, G. I. 1986. Density and viscosity gradients in zoned magma chambers, and their influence on withdrawal dynamics. Journal of Volcanology and Geothermal Research 30, 201-30.

Brown, G. M. 1969. The Tertiary Igneous Geology of the Isle of Skye. Geologists' Association Guide No. 13.

Bryan, W. B., Finger, L. W. \& Chayes, F. 1969. Estimating proportions in petrographic mixing equations by least squares approximation. Science 163, 1926-7.

Basaltic VolCanism Study Project (BVSP). 1981. Basalt Volcanism on the Terrestrial Planets. Pergamon.

Carmichael, I. S. E., Turner, F. J. \& Verhoogen, J. 1974. Igneous Petrology. New York: McGraw-Hill.

Chesher, J. A., Smythe, D. K. \& Bishop, P. 1983. The Geology of the Minches, Inner Sound and Raasay. Institute of Geological Sciences Report, 83/6.

Donaldson, C. H. 1976. An experimental investigation of olivine morphology. Contributions to Mineralogy and Petrology 57, 187-213.

Drever, H. I. 1953. A note on the field relations of the Shiant Isles picrite. Geological Magazine 90, 159-60.
Drever, H. I. \& Johnston, R. 1957. A note on the occurrence of rhythmic layering in the Eilean Mhuire sill, Shiant Isles. Geological Magazine 94, 277-80.

Drever, H. I. \& Johnston, R. 1959. The lower margin of the Shiant Isles sill. Quarterly Journal of the Geological Society of London 94, 343-65.

DREVER, H. I. \& JOHNSTON, R. 1965. New petrographical data on the Shiant Isles picrite. Mineralogical Magazine 34, 194-203.

DREVER, H. I. \& Johnston, R. 1967. The ultrabasic facies in some sheets and sills. In Ultramafic and Related Rocks (ed. P. J. Wyllie), pp. 51-63. New York: Wiley.

Dunham, A. C. 1965. A new type of banding in ultrabasic rocks from central Rhum, Inverness-shire, Scotland. American Mineralogist 50, 1410-20.

Frey, F. A., GreEN, D. H. \& Roy, S. D. 1978. Integrated models of basalt petrogenesis: a study of quartz tholeiites to olivine melilitites from South Australia utilizing geochemical and experimental petrological data. Journal of Petrology 19, 463-513.

GIBB, F. G. F. 1973. The zoned clinopyroxenes of the Shiant Isles sill, Scotland. Journal of Petrology 14, 203$3 n$

GibB, F. G. F. \& Gibson, S. A. 1989. The Little Minch Sill Complex. Scottish Journal of Geology 25, 367-70.

GibB, F. G. F. \& Henderson, C. M. B. 1984. The structure of the Shiant Isles sill complex, Outer Hebrides. Scottish Journal of Geology 20, 21-9.

GibB, F. G. F. \& Henderson, C. M. B. 1989. Discontinuities between picritic and crinanitic units in the Shiant Isles sill : evidence of multiple intrusion. Geological Magazine 126, 127-37.

Gibson, S. A. 1990. The geochemistry of the Trotternish sills, N. Skye, Scotland: crustal contamination in the British Tertiary Volcanic Province. Journal of the Geological Society, London 147, 1071-81.

HupPERT, H. E. \& SPARKS, R. S. J. 1989. Chilled margins in igneous rocks. Earth and Planetary Science Letters 92 $397-405$.

MurRaY, R. J. 1954. The clinopyroxenes of the Garbh Eilean sill, Shiant Isles. Geological Magazine 91, $17-31$.

Murata, K. J. \& RichteR, D. H. 1976. The 1959-1960 eruptions of Kilauea volcano, Hawaii; chemistry of the lavas. U.S. Geological Survey Professional Paper 537A, $1-26$.

Nash, W. P. \& Wilkinson, J. F. G. 1970. Shonkin Sag Laccolith, Montana. 1. Mafic minerals and estimates of temperature, pressure, oxygen fugacity and silicaactivity. Contributions to Mineralogy and Petrology 25, 241-69.

Roeder, P. L. \& Emslie, R. F. 1970. Olivine-liquid equilibrium. Contributions to Mineralogy and Petrology 29, 275-89.

Simkin, T. 1967. Flow differentiation in the picritic sills of north Skye. In Ultramific and Related Rocks (ed. P. J. Wyllie), pp. 64. New York: Wiley.

Sparks, R. S. J., Huppert, H. E., Kerr, R. C., McKenzie, D. P. \& TAIT, S. R. 1985. Postcumulus processes in layered intrusions. Geological Magazine 122, 55568.

WAGER, L. R. \& BRown, G. M. 1967. Layered Igneous Rocks. Edinburgh: Oliver \& Boyd.

WALKER, F. 1930. The geology of the Shiant Isles (Hebrides). Quarterly Journal of the Geological Society, London 86, 355-98. 
WalKer, F. 1931. The dolerite isles of the North Minch. Transactions of the Royal Society of Edinburgh 56, 753-66.

WALKER, F. 1932. Differentiated sills of Northern Trotternish (Skye). Transactions of the Royal Society of Edinburgh 57, 241-57.
WILKINSON, J. F. G. 1957. The clinopyroxenes of a differentiated sill near Guennedah, New South Wales. Geological Magazine 94, 123-34.

Young, I. M. \& Donaldson, C. H. 1985. Formation of granular layers within the Rhum crystal pile. Geological Magazine 122, 519-28. 